\title{
Theoretical Considerations on the Evolution of Sombart's Center-Periphery Model
}

Vlad I. ROȘCA ${ }^{1}$

\begin{abstract}
This historical essay looks at how the center-periphery model has developed over the twentieth century. The analysis begins from Werner Sombart's industrialagrarian cleavage and carries on to identify how the model has been altered during the years. Apart from Sombart's incipient phase, the paper identifies three other distinct periods that have contributed to the evolution of the center-periphery dichotomy: the postbelic recovery of nations up to the mid-1970's, a second period situated between 1975 and the fall of the Iron Courtain (strongly influenced by the works of Shils) and, last but not least, the post-1990 'polycentric development' era. By analyzing these distinct periods, the research comes to the conclusion that center-periphery relationships have known different characteristics, from a periphery heavily reliant on knowledge and technology to be transferred from the center, to a more autonomous periphery closer to our days, aspiring to converge with the center by using more of its own forces.
\end{abstract}

Keywords: center-periphery, convergence, world economy, technology transfer

JEL classification: F02, F40, F50, F60

DOI: $10.24818 /$ RMCI.2018.1.77

\section{Introduction}

This article takes the form of a historical essay with the purpose of identifying a red line in the evolution of center-periphery theories over the past century. The analysis aims to follow the progression of major thoughts and ideas that economists have contributed with to the center-periphery model. The starting point is Werner Sombart's call made to his comrade economists at the start of the twentieth century to discern between industrialized and non-industrialized states when analyzing economic development. Sombart, controversial German economist and social scientist, published his groundbreaking work, Der moderne Kapitalismus, in 1902, focusing on how economy has developed over time (Brocke, 1992; Chaloupek, 1995; Grundmann, Stehr, 2001; Krumme, 1968; Lenger, 2012). One of his main ideas was that economies unfold at different paces and that comparative studies need to take these disparate speeds into account. Sombart, dubbed as Left-Wing Nietzschean (Taylor, 1990: 58), has been, to a certain extent, influenced by the German social movement orientation (Giddens, 1970; Parsons, 1928; Sharlin, 1972; Wearne, 1989). It was from this perspective that Sombart saw the emergence of a new form of economy, capitalism, which was

${ }^{1}$ Vlad I. Roșca, The Bucharest University of Economic Studies. E-mail: vlad_rsc@yahoo.com 
preoccupied with increasing the value of products, monetization and lowering costs (Kobrin, Teller, 2015), and which he did not restrain from praising in patches. Later in his life, Sombart returned to arguing that successful economies would be led by socialism (Bell, 1996) and that bourgeois economies would collapse (Sombart, 1913), hence creating a division between capitalism and socialism. It is not the topic of this study to assess Sombart's argument, but only to acknowledge his claim of looking at economies in different ways (Love, 1996: 233). By claiming the divide, Sombart brought the idea of a "center-periphery" dichotomy in economics (Love, 1994: 419; 2011: 26). Originally formulated in Sombart's 1902 work (Nates Cruz, 2011), the paradox has known several changes throughout history, yet there is no clear overview of the major economic contributions, which, in the lapse of time, have shaped "center-periphery" theories to their modern form. In attempting a historical analysis of evolution, the research questions asks: "What has been the progression of center-periphery theories in economics over the $X X^{\text {th }}$ century?"

While trying to answer the question, the essay identifies four distinct changes which will be further analyzed. Sombart's starting point of a capitalist nation that ought to be differentiated from other co-existing 'wooden age' nations (Radkau, 2013) is followed by a postbelic theory according to which economies have recovered at different paces after the two grand wars. As much as Sombart has come up with the idea of the two speeds, it is this post-war school of thought that has shaped much of what "center-periphery" cleavage means in its current form. This second stage, impacted by the realities of afterwar freedom, has largely failed due to the fact that it considered national states to be equal, to be partners with the same rights. Shils (1975) used this breach to claim this should not be true, arguing that some of the states are at the center, while other at the periphery, with central states exerting authority over marginal states. Shils' idea emphasized the importance of power in binary relationships, upheaving dependency theories: the more dependent on the center are the peripheral states, the more powerful the center is. This third stage contributed to theory development through the idea that peripheries are reliant to the center. Last but not least, convergence efforts made by the European Union and other transational institutions presented in this article after 1990, have led to a fourth stage of development, which scientists have called "polycentric development", characterized by the fact peripheries are not necessarily dependent on the center, but that they can exist and develop by themselves, just that, for the moment being, there is a gap to be bridged.

\section{Theoretical Considerations}

Albeit its spatial overtones, which would rather make it the appanage of spatial research, center-periphery models have been largely studied by economists. In a landscape perspective, the center-periphery relationship describes the distance between an outskirt and the center (Buhaug et al., 2008; Kuang, 2012; Radović, 2008). What started as a geographical divide later on turned into a socio-spatial 
metaphor (Agnew, Boiling, 1993; Deane, 1995; Montencios, Markoff, 2010; Scott, Marshall, 2009). The "center-periphery" dichotomy has broken through physical barriers and has come to symbolise the relationship between an evolved center and a backboned periphery, i.e. as a figure used to justify the idea of the establishment (Bianchi, 2002). The center (the establishment) is the point - but, in a metaphorical sense, also the idea/ideology - that is the most important in relation to a specific activity (e.g. in economics, the center would be occupied by the most powerful, developed economies), possessing the administrative power of organizing, while the periphery lies at the center's borders (Mardin, 1973; Woods, 1995; Wright, 1991).

Odd enough, economic geography (how economic proxies like economic agents or factors of production are located into space) has received less attention in science if compared to trade theories, which look at states as agents that need to exchange goods and services for money, irrespective of their location. While location is important, many of the 'hardcore' economic studies have chosen to focus on monetary and financial analyses at the cost of space, leaving geography to play the role of a niche in the wider area of economic research. Krugman (1991) considered this disregard as surprisingly to say the least, because of the momentous role that geography plays in providing access to resources and, subsequently, in how an economy fares on the international scene. The economic inequalities that have been gradually created all over the world (O'Rourke, Williamson, 2001) have endorsed the importance of studying the relationship between the developed and underdeveloped societies, with the center-periphery relationship being employed as a metaphor which, after its success in economics, came to characterize abstract matters as well (Akli, 2009: 30; Spitzer, 2015: 57) - i.e. societal, cultural, religious or philosophical. Incipient theories in economic sciences can be attributed to Sombart (1902), who justified the division of economies into development stages, focusing his seminal work on the servitude of peasantry and their relationship to the ruling class representing the center (Love, 1996).

As science and economy have developed, center-periphery relationships have been transformed into models. What Sombart had offered at the dawn of the previous century was a mere call to fellow economists to distinguish between capitalist nations (which he regarded as the powerhouse of international economic relationships, dictating paths of economic action) and the rest of the states, who were only passive actors (Love, 1994: 419). Sombart's perception has arguably been shaped by England, the economic force during his early life, a country that benefitted from the Industrial Revolution to accelerate its economy and set the grounds of modern capitalism. Taylor (1990) draws a picture of Sombart's thought by characterizing it as a mix of English mercantilism and German fortitude (Taylor, 1990: 58). For the beginning, England set the tone by itself, to be later joined by other Western European countries, which made Sombart consider the existence of distinctive development stages of the economy, with less developped nations gradually taking over technology and innovation from nations that have already undergone a higher phase of economic development and for whom that 
particular novelties which are now taken over have become altered. Alike many other economists of his ages, Sombart saw a direct connection between Industrial Revolution and Capitalism. As England enjoyed a flagship role in the industrialization of economic goods production, Sombart considered it to be a 'center' of global economy, which, aided by the United States of America, was able to impose its dominance over Central and Eastern European states, hence the need to be differentiate that 'center' from other, still non-industrialized, southern and oriental countries of the Old Continent (Fitzgerald, 1991). The same is confirmed by Lomnitz (2001: 166), who classifies XIX ${ }^{\text {th }}$ century Britain as central to the global economy, while same century India, even if under the British Raj, only as peripheral. Sombart considered that, with such an availability of power, Britain was able to impose its rule over the CEE states, especially in what concerned obtaining trade benefits (Nederveen Pieterse, 2001: 39). To better explain the "industrialization vs. non-industrialization" dichotomy that has led to his main argument, Sombart used the metaphor of the 'wooden age' (Warde, 2006: 6): although existing at the same time in history, some states (i.e. Central and Eastern European) were still at wooden age level, using wood to support economic production, while England accelerated with the help of the steam engine, a technological advancement which history proved would soon after be taken over by other national economies as well.

However, apart from mentioning that less developped economies follow in the footsteps of other better developped ones, Sombart did not provide any particular analysis on the center-periphery dichotomy. Thorough scientific evidence in support of Sombart's idea can only be identified after the end of the World Wars, the early $\mathrm{XX}^{\text {th }}$ century postbelic studies going back to the roots pinpointed by Sombart to underline that the world recovered at different paces from war aftermaths (Huang, 2013: 22; Ohanian et al., 2013: 2). If Sombart has put his idea in the frames of the Industrial Revolution, many of the building blocks of the research have been set in correlation with the events in 1914-1918 and 19391945. Mid-century models were employed to highlight how post-war capitalism was deployed at different speeds throughout the world (Batur, 2014). While France, Switzerland or the United Kingdom have witnessed economic expansion and monetary stability at the start of the 1950's (Brenac, 1956; Bundi, 2005), earlier developments at the Yalta and Potsdam Conferences had already set the stage of a continent at "two speeds", influencing the destinies of millions for the upcoming half of the century (Chowdhury, 1990; Omel'chuk, Iurchenko, 2002) and dividing Europe into capitalist and socialist, a bipolarity that Appelqvist (2008) continues to see as a problem of research even after the 1990's reconcilliation of former Eastern Block states. Although many authors (Myers et al., 1986; Sik, 2017) consider that socialist economies develop faster because of the powerful interventions of the state party (and, in this case, they come to terms with Sombart's idea and wish of the prevailing socialism which would take central stage over peripheral capitalism), on the longer run, structural developments speak for the free market economy of the 'centralized' West, while the 'peripheral' East has 
demonstrated to gradually downgrade to underdevelopment after the fall of the Iron Courtain. The density of inequalities witnessed in Europe has led to a resuscitation of Sombart's idea of central and marginal economies, only with a different trigger.

A second stage in taking Sombart's considerations further can be traced towards the early end of the twentieth century, especially through the work of Shils who famously claimed that 'society has a center' (1975: 3). Suggesting that there is a core placing its hegemony over outsiders, the argument has created a vast amount of work that focused on explaining the characteristics which made the 'center' have a distinct role in society. A characteristic of the $\mathrm{XX}^{\text {th }}$ century center-periphery studies is that the two parties do not behave as partners, but according to a ranking where the center has the power and the periphery obeys. Migdal (2001: 44) believes that a center is meant to exert authority and power over its surroundings. Authority and power are attributes pertaining to the center, having been created as a result of elitism, institutionalism, order and harmony. All of these values are posessed by the center, and although Shils mentions that they are desirable for the entire society, their availability is restricted to a certain group (the center itself), which has been able to accelerate them through the existence of an institutional system. Institutions are important because they create action. One of the major misachievements of the periphery is the lack of a well-functioning institutional ensemble. Actions do not crop up there where institutions are missing (Lecours, 2005: 8). In Shils' view, the center is able to impose order thanks to the good institutional organization. Actions are a result of the decisions made in institutions. At the same time, institutional decision-making would lack quality without the elites: the best trained people of their class brought together within an institution. The co-existence of order, institutions and elites makes the center be adored and looked upon with reverence, as a symbolic area which, thanks to its advances, is the leader of a group. For the rest is built up by the periphery, a symbolic region that lacks all the qualities of the center. It has neither institutions, nor elites or harmony. In Shils' analysis, the periphery is nothing else than a mere external boundary, receiving limited attention. As a matter of fact, one piece of the dichotomy can be explained as being the opposite of the other. This and the fact that, in his view, wealth can only be created by the center, have probably made Shils to leave the periphery be explained by opposition. Shils finds no way in which periphery can create advancements than by passively transferring them from the center. In his view, how peripheries are organized is less important as they simply have to transfer and adpat what has been proven to work in the center.

In economics, the center-periphery model uses exchanges in order to sustain itself: the periphery transfers knowledge and technology from the center in exchange of resources (Ko, Lee, 2012). This idea lets itself explained through the methaphorical theory of network nodes. Imagining a concentric circle, the "center" is the inside of the circle, surrounded by a vaster, outer circle: the periphery. The circle represents the relationship between the two nodes. The smaller dimensions of the centric circle represent its elitism: an accumulation of values at the core, restrictive towards the external boundaries. Stevenson and Greenberg (2000) 
believe that the center certainly has more alternatives than the periphery thanks to its easy and open access to resources, increasing the dependence of others on it. The higher the number of dependent agents in the network, the more elitist the center, which means that its size within the circle will diminish due to the enlargement of the exterior circle of dependent agents, which ultimately leads to the center enjoying more power and authority, being in a priviledged position to decide about the fate of the rest. At this point, a third post-sombartesque stage in the development of economic center-periphery theories can be identified, springing from alignment efforts made by transnational bodies such as the European Union after the 1990's. These efforts have helped backstage economies to develop, making Koliba et al. (2017) to argue that, although less powerful, the periphery is not powerless. In a concentric relationship, power flows between the agents, and it is often the center itself that delegates power to the periphery. Distinctive to Sombart's very first studies, where periphery received a truly obsolete role, global efforts to develop economies (epitomized through the existence of bodies such as the WTO, IMF, EU, UNCTAD etc.) have granted the periphery a status of pending towards centralism. In Copus' (2001) view, over the past hundred years, the economy has moved from a "center-periphery" design to a "polycentric" development: IT\&C advancements and structural changes influenced a spatial reorganization, granting more power to peripheries and allowing them to accelerate their catch-up race with the center. Analyzing wider, global perspectives in what concerns the inequalities in economic development, Prebisch (1950) made a point that peripheral nations closer to the center of the circle have more benefits derived from their connection to the center than nations situated further away. The closer a peripheral state to the center of the circle, the more advantages it will be able to derive from the center. Prebisch's idea also explains that there are more categories of peripheral states, their quality depending on how close their ties are with the center. In part, Prebisch adds a nuance to the idea of Koliba et al.: some peripheries are more powerful than others, several of them being closer to a better economic status, while others still dwelling in poverty. At the same time, the advancements mentioned by Copus (2001) enable a gradual move towards the center, with some peripheral states joining the centers, while other previously sub-peripheral states being able to take over their position and to aspire to a better future. As a matter of fact, Copus argues that peripherality should probably be replaced by an 'aspirational' model, according to which different nations converge and aspire, at the same time - without needing to wait that a slot above them is released - to align with the center.

\section{Conclusions}

The center-periphery divide is a model suitable for analyzing international relationships in any kind of specialization: economics, law, sports, anthropology, culture etc. (Hannerz, 1989). Observing the global economy as an establishment of two distinct halves, with a powerful center dominating an adjunct periphery, is the 
core of this model, which proves useful for development/underdevelopment analyses (De Janvry, Garramón, 1977; Love, 1980a). Having the center as a term of comparison (and representing the utmost of evolution) lets economist make an idea of how developed the periphery is. Sombart himself saw the center in industrialized countries, while agrarian countries were forming the periphery. Center-periphery analyses are by nature comparative studies, as the peripheries need to be compared to the center in order for the researchers to be able to draw conclusions on the state of progress. For Sombart, progress meant that backward agrarian countries make the effort to align with industrialized societies (Boatcă, 2005: 17). At the same time, the center would have to difuse value, ideas and knowledge, and institutionalize them accross the periphery (Patiniotis, 2013). The logic of diffusion and alignment was maintained in the decades to come, just that the industrial-agrarian model was replaced by the realities post second world war, with the race of nations to rebecome what they once were. Observing that postbelic recovery occured at different speeds, scientists coined the peripheral states as being the ones retrieving power at lowest speeds, opening the doors for Shils (1975) to argue that society has a center which dominates. Once knowledge and technologies become outdated for the center, they should be taken over by peripheries, while the center further on continues to innovate. This diffusion model asserts the passive role of peripheries as beneficiaries of aged technologies from the center. However, over the past couple of decades, the role of peripheries has changed from a passive observer to an active player. In Sombart's incipient idea, peripheral states belonged to passive regions of the world which were controlled by active, capitalist zones, situated at the center (Love, 1980b). The so called 'power wars' of the modern world economy have fuelled the aspirations of peripheral states to become just as good as central states ( $\mathrm{Su}, 1995)$. This made peripheries to assume more responsibilities and start a work of their own to come closer to the center, not waiting to benefit from transferred knowledge, but actively working on their development. This last stage in the evolution of the center-periphery model, witnessed after the 1990's, can be called the "aspirational" era of peripheries, as the latter ones aspire to align with the center by breaking loose of their passive condition.

\section{References}

1. Agnew, J., \& Boiling, K. (1993): "Two Romes or more? The use and abuse of the center-periphery metaphor", Urban Geography, 14(2), pp. 119-144.

2. Akli, M. (2009): "Conventional and Original Metaphors in French Autobiography", Peter Lang Publishing, Inc., New York.

3. Appleqvist, Ö. (2008): "Rediscovering uncertainty: early attempts at a panEuropean post-war recovery", Cold War History, 8(3), pp. 327-352.

4. Batur, S. (2014): "Center and Periphery", in Thomas Teo (ed.): Encyclopedia of Critical Psychology, Springer, New York, pp. 212-215. 
5. Bell, D. (1996): "Marxian Socialism in the United States", Cornell University Press, Ithaca/London.

6. Bianchi, A. M. (2002): "For different audiences, different arguments: economic rhetoric at the beginning of the Latin American School", Journal of the History of Economic Thought, 24(3), pp. 291-305.

7. Boatcă, M. (2005): "Peripheral solutions to peripheral development: the case of early 20th century Romania", Journal of World-Systems Research, 11(1), pp. 3-26.

8. Brenac, P. (1956): "The post-war recovery of France", Australian Outlook, 10(2), pp. 17-54.

9. Brocke, B. V. (1992): "Werner Sombart (1863-1941) Capitalism-SocialismHis Life, Works and Influence Since Fifty Years", Jahrbuch für Wirtschaftsgeschichte/Economic History Yearbook, 33(1), pp. 115-184.

10. Buhaug, H., Cederman, L. E., Rød, J. K. (2008): "Disaggregating ethnonationalist civil wars: A dyadic test of exclusion theory", International Organization, 62(3), pp. 531-551.

11. Bundi, M. (2005): "Erhalten und Gestalten: 100 Jahre Schweizer Heimatschutz", Hier + Jetzt, Verlag für Kultur und Geschichte GmbH, Baden.

12. Chaloupek, G. (1995): "Long-term economic perspectives compared: Joseph Schumpeter and Werner Sombart", Journal of the History of Economic Thought, 2(1), pp. 127-149.

13. Chowdhury, G.W. (1990): "From Yalta to Malta", Journal of East and West Studies, 19(1), pp. 85-96.

14. Copus, A.K. (2001): "From Core-periphery to Polycentric Development: Concepts of Spatial and Aspatial Peripherality", European Planning Studies, 9(4), pp. 539-552.

15. Deane, P. D. (1995): "Metaphors of center and periphery in Yeats' The Second Coming", Journal of Pragmatics, 24(6), pp. 627-642.

16. De Janvry, A., Garramón, C. (1977): "Laws of motion of capital in the centerperiphery structure", Review of Radical Political Economics, 9(2), pp. 29-38.

17. Fitzgerald, E.V.K. (1991): "ECLA and the formation of Latin American economic doctrine in the nineteenforties", Institute of Social Studies, The Hague.

18. Giddens, A. (1970): "Marx, Weber, and the development of capitalism", Sociology, 4(3), pp. 289-310.

19. Grundmann, R., \& Stehr, N. (2001): "Why is Werner Sombart not part of the core of classical sociology? From fame to (near) oblivion", Journal of Classical Sociology, 1(2), pp. 257-287.

20. Hannerz, U. (1989): "Culture between center and periphery: Toward a macroanthropology", Journal of Anthropology, 54(3-4), pp. 200-216.

21. Huang, X. (2013): "Mapping Japan and China in the World Economic System", in Xiaoming Huan (ed.), Modern Economic Development in Japan and China: Developmentalism, Capitalism, and the World Economic System, Palgrave Macmillan, Basingstoke/New York, pp. 10-36. 
22. Ko, S., Lee, K.W. (2012): "Risks and Opportunities of the Energy Sector in East Siberia and the Russian Far East: For Better Risk Management and Sustainable Energy Development", LIT Verlag, Münster.

23. Kobrin, R., Teller, A. (eds.) (2015): „Purchasing Power: The Economics of Modern Jewish History", University of Pennsylvania Press, Philadelphia.

24. Koliba, C., Meek, J.W., Zia, A., Mills, R. (2017): “Governance Networks in Public Administration and Public Policy", Routledge, Oxon/New York.

25. Lecours, A. (2005): "New Institutionalism: Theory and Analysis", University of Toronto Press, Toronto.

26. Krugman, P. (1991): "Increasing returns and economic geography", Journal of Political Economy, 99(3), pp. 483-499.

27. Krumme, G. (1968): "Werner Sombart and the economic base concept", Land Economics, 44(1), pp. 112-116.

28. Kuang, W. (2012): "Spatio-temporal patterns of intra-urban land use change in Beijing, China between 1984 and 2008”, Chinese Geographical Science, 22(2), pp. 210-220.

29. Lenger, F. (2012): "Werner Sombart 1863 - 1941: Eine Biographie", 3. Auflage, C.H. Beck Verlag, München.

30. Lomnitz, C. (2001): "Deep Mexico, Silent Mexico: An Anthropology of Nationalism", University of Minnesota Press, Minneapolis/London.

31. Love, J. L. (1980a): "Raul Prebisch and the origins of the doctrine of unequal exchange", Latin American Research Review, 15(3), pp. 45-72.

32. Love, J. L. (1980b): “Third World'a response to professor Worsley”, Third World Quarterly, 2(2), pp. 315-317.

33. Love, J.L. (1994): "Economic ideas and ideologies in Latin America since 1930", in Leslie Bethell (ed.), The Cambridge History of Latin America, Volume VI, Part 1: 1930 to Present, Chapter 7, pp. 393-462, Cambridge University Press, Cambridge/New York/Melbourne.

34. Love, J.L. (1996): "Economic ideas and ideologies in Latin America, 1870-1930", in Leslie Bethell (ed.), Ideas and Ideologies in Twentieth-Century Latin America, Chapter 3, pp. 207-274, Cambridge University Press, Cambridge/New York/Melbourne.

35. Love, J.L. (2011): "The Latin American Contribution to Center-Periphery. Perspectives: History and Present", in Peter Hanns Reill, and Balázs A. Szelény (eds.), Cores, Peripheries, and Globalization: Essays in Honor of Ivan T. Berend, Chapter 1, pp. 15-42, Central European University Press, Budapest/New York.

36. Love, L.R. (1996): "Crafting the Third World: Theorizing Underdevelopment in Rumania and Brazil", Stanford University Press.

37. Mardin, Ş. (1973): "Center-periphery relations: A key to Turkish politics?", Daedalus, 102(1/Post-Traditional Societies), pp. 169-190.

38. Montencios, V., Markoff, J. (eds.) (2010): "Economists in the Americas", Edward Elgar Publishing, Cheltenham/Northampton, MA. 
39. Myers, J.T., Domes, J., von Groeling, E. (1986): “Chinese Politics: Fall of Hua Kuo-Feng (1980) to the Twelfth Party Congress (1982)", University of South Carolina Press, South Carolina.

40. Nates Cruz, B. (2011): "Theoretical and ethnographical supports on territory concepts", Revista Co-herencia, 8(14), pp. 209-229.

41. Nederveen Pieterse, J. (2001): "Development Theory: Deconstructions / Reconstructions", $1^{\text {st }}$ Edition, SAGE Publications, Thousand Oaks.

42. Ohanian, L.E., Taylor, J.B., Wright, I. (2013): "Government Policies and the Delayed Economic Recovery", Hoover Press, Stanford.

43. Omel'chuk, D., Iurchenko, S. (2002): "The Crimean (Yalta) Conference", Russian Politics \& Law, 40(3), pp. 82-92.

44. O'Rourke, K. H., Williamson, J. G. (2001): "Globalization and history: the evolution of a nineteenth-century Atlantic economy", MIT Press, Cambridge / London.

45. Parsons, T. (1928): "Capitalism" in recent German literature: Sombart and Weber", Journal of Political Economy, 36(6), pp. 641-661.

46. Patiniotis, M. (2013): "Between the Local and the Global: History of Science in the European Periphery Meets Post-Colonial Studies", Centaurus, 55(4), pp. 361-384.

47. Prebisch, R. (1950): “The Economic Development of Latin America and its principle problems", United Nations Department of Economic Affairs, Lake Success, New York.

48. Radkau, J. (2013): "Wood: A History", John Wiley \& Sons, Hoboken, NJ.

49. Radović, S. (2008): "From Center to periphery and vice versa: The politics of toponyms in the transitional capital", Glasnik Etnografskog Instituta SANU, 56(2), pp. 53-74.

50. Scott, J., Marshall, G. (2009): “A Dictionary of Sociology”, 3 rev. ed., Oxford University Press, Oxford.

51. Sharlin, A. (1972): "Werner Sombart: A Study in the Relationship Between Social Science and Politics", University of Wisconsin, Madison.

52. Shils, E. (1975): „Center and periphery: essays in macrosociology”, University of Chicago Press, Chicago.

53. Sik, O. (2017): "Revival: Czechoslovakia (1972): The Bureaucratic Economy", Routledge, Oxon/New York.

54. Sombart, W. (1902): "Der moderne Kapitalismus", Duncker \& Humblot.

55. Sombart, W. (1913): “The Jews and Modern Capitalism", E.P. Dutton \& Company, New York.

56. Spitzer, M. (2015): "Metaphor and Musical Thought", University of Chicago Press, Chicago, IL.

57. Stevenson, W.B., Greenberg, D. (2000): “Agency and Social Networks: Strategies of Action in a Social Structure of Position, Opposition, and Opportunity", Administrative Science Quarterly, 45(4), pp. 651-678. 
58. Su, T. (1995): "Three Logics of "Major Power Rivalry" in the World-System: A Footnote to a Pentagon study", Journal of World-Systems Research, 1(1), pp. 483-496.

59. Taylor, S. (1990): "Left-Wing Nietzscheans: The Politics of German Expressionism 1910-1920", Walter de Gruyter, Berlin/New York.

60. Warde, P. (2006): „Ecology, Economy and State Formation in Early Modern Germany", Cambridge University Press, Cambridge.

61. Wearne, B.C. (1989): "The Theory and Scholarship of Talcott Parsons to 1951: A Critical Commentary", Cambridge University Press, Cambridge.

62. Woods, D. (1995): "The crisis of center-periphery integration in Italy and the rise of regional populism: The Lombard League", Comparative Politics, 27(2), pp. 187-203.

63. Wright, T.P. (1991): "Center-periphery relations and ethnic conflict in Pakistan: Sindhis, Muhajirs, and Punjabis", Comparative Politics, 23(3), pp. 299-312. 